\title{
Continuous quantitative mapping of multi-organ T1 relaxation times with ShMOLLI to assess dose response in respiratory challenges at $3 \mathrm{~T}$
}

\author{
SK Piechnik*, V Ferreira, S Neubauer, MD Robson \\ From 16th Annual SCMR Scientific Sessions \\ San Francisco, CA, USA. 31 January - 3 February 2013
}

\section{Background}

The performance of T1 mapping as a stable biomarker depends on its sensitivity to pathological changes and relative insensitivity to normal physiological variations or common clinical interventions, such as oxygen administration. We address the impact of breathing air supplemented with oxygen $(\mathrm{O} 2)$ and/or carbon dioxide $(\mathrm{CO} 2)$ on $\mathrm{T} 1$ values in healthy myocardium and selected extra-cardiac tissues.

\section{Methods}

6 normal control volunteers (age $35 \pm 4$ years, 2 females) underwent serial T1-mapping using the Shortened Modified Look Locker Inversion Recovery (ShMOLLI, Piechnik et al. JCMR 2010, 12:69) at 3T (Siemens Trio). Subjects breathed through a mouthpiece to allow monitoring of $\mathrm{O} 2$ and $\mathrm{CO} 2$ content (Datex Normocap 200) during three 15-minute respiratory challenges as follows: 4 minutes of normal air, 5 minutes of supplemented target mixture with $\mathrm{O} 2(21-100 \%)$ and $\mathrm{CO} 2(0-5 \%)$, and 6 minutes of normal air (Fig. 1A). T1-mapping was performed back-to-back at end-expiration under automated breathing instructions. Regions of interest (ROIs) were drawn on T1 maps within the myocardium, left ventricular (LV) and right ventricular (RV) blood pools, liver parenchyma excluding major vessels, and the spleen. ROIs were followed semi-automatically for motion between breath-holds. The relationship between changes in $\mathrm{T} 1$ in each organ and the end-tidal (Et) gas content was assessed using general linear modelling.

Cardiovascular Medicine, University of Oxford, Oxford, UK

\section{Results}

Each $1 \%$ increase in $\mathrm{O} 2$ and $\mathrm{CO} 2$ resulted in a 0.76 $\pm 0.2 \%$ and $0.3 \pm 0.04 \%$ change in end-tidal content, respectively. T1 maps were acquired typically every 23 seconds ( $<25 \mathrm{~s}$ in $95 \%$ of the 701 measurements). Following $\mathrm{O} 2$ administration, LV blood and spleen demonstrated clear and visible lowering in $\mathrm{T} 1$ trendlines (Fig. 1B) and directly on colour T1 maps (Fig. 2AB) and. The relationships showed significant negative linear regression slopes of $-3.5 \pm 0.2 \mathrm{~ms} / \% \mathrm{EtO} 2(\mathrm{R} 2=0.94)$ and $-2.6 \pm 0.4 \mathrm{~ms} / \% \mathrm{EtO} 2(\mathrm{R} 2=0.69)$, respectively (Fig. $1 \mathrm{C}$ ). There was no relationship between T1 in LV blood or spleen with $\mathrm{CO} 2$. T1 in healthy myocardium was not sensitive to changes in $\mathrm{O} 2$. Myocardial $\mathrm{T} 1$ increased

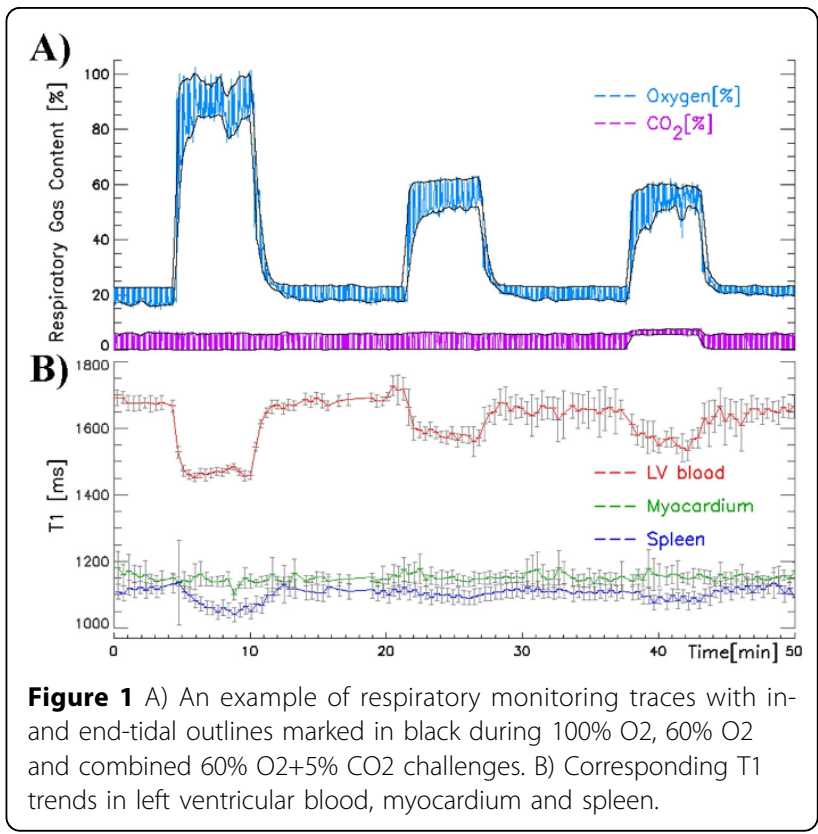




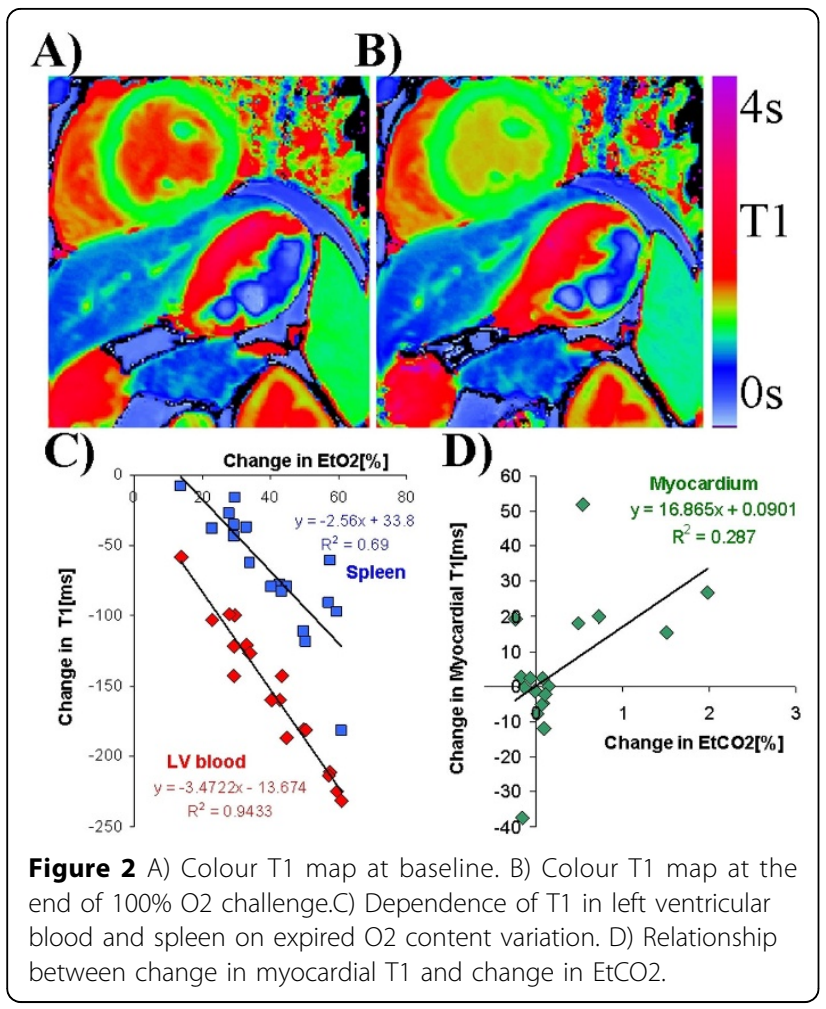

slightly with $\mathrm{CO} 2$ administration $(+17 \pm 7 \mathrm{~ms} / \%$ EtCO2, $\mathrm{R} 2=0.29)$, corresponding to only a $3 \%$ deviation from baseline $\mathrm{T} 1$ within the limits of a typical $5 \% \mathrm{CO} 2$ vasodilatory challenge (Fig. 1D). T1 in RV blood and liver did not correlate with $\mathrm{O} 2$ or $\mathrm{CO} 2$ content.

\section{Conclusions}

ShMOLLI T1-maps can be acquired at a frequency of up to 3 per minute with excellent measurement consistency over extended periods of time, with potential use in the monitoring of physiological effects of respiratory challenges. T1 directly detects hyperoxygenation in arterial blood and its propagation downstream to some major organs such as the spleen. There was little evidence of major variation of $\mathrm{T} 1$ with $\mathrm{O} 2$ or $\mathrm{CO} 2$ in the other organs studied. Specifically, in comparison to normal T1 variability, myocardial T1 is relatively stable under feasible hyperoxia and hypercapnia.

\section{Funding}

National Institute for Health Research (NIHR) Oxford Biomedical Research Centre.

Published: 30 January 2013

\section{doi:10.1186/1532-429X-15-S1-W9}

Cite this article as: Piechnik et al: Continuous quantitative mapping of multi-organ $\mathrm{T} 1$ relaxation times with ShMOLLI to assess dose response in respiratory challenges at 3T. Journal of Cardiovascular Magnetic Resonance 2013 15(Suppl 1):W9.
Submit your next manuscript to BioMed Central and take full advantage of:

- Convenient online submission

- Thorough peer review

- No space constraints or color figure charges

- Immediate publication on acceptance

- Inclusion in PubMed, CAS, Scopus and Google Scholar

- Research which is freely available for redistribution 